\title{
Circulating Plasma Albumin mRNA as a Predictor of Liver Injury in Chronic Hepatitis $\mathrm{C}$ and Hepatocellular Carcinoma
}

\author{
Yasser F Thabet ${ }^{1}$, Mohammed Akl Rady ${ }^{2}$, Maha Sabawi ${ }^{2}$, Ghada R El Hendawy ${ }^{3}$, Tawfik M Abd El \\ Mottaleb $^{4}$, Mervat Mohii ${ }^{5}$, Soumaya Suliman', Waleed N Hassan ${ }^{6 *}$ \\ ${ }^{1}$ Department of Clinical Pathology, National Liver Institute, Menoufiya University Egypt \\ ${ }^{2}$ Department of Hepatology, National Liver Institute, Menoufiya University Egypt \\ ${ }^{3}$ Department of Microbiology, Faculty of Medicine, Menoufiya University Egypt \\ ${ }^{4}$ Department of Microbiology, National Liver Institute, Menoufiya University Egypt \\ ${ }^{5}$ Department of Clinical Pathology, Al Azhar Faculty of Medicine for Girls, Egypt \\ ${ }^{6}$ Department of Internal Medicine, Al Azhar Faculty of Medicine for Girls, Egypt \\ ${ }^{7}$ Department of Biochemistry, Menoufiya Faculty of Medicine, Egypt \\ *Corresponding Author: \\ Waleed N Hassan MD, PhD \\ Department Of Biochemistry \\ Faculty of Medicine, Menoufiya University \\ Shebin El-Kom, Egypt \\ E mail: waleednh@yahoo.com
}

Received: 6 June 2011; | Revised: 16 June 2011; | Accepted: 1 August 2011

\begin{abstract}
Background: Analysis of circulating nucleic acids in plasma, such as cell free RNA offers an avenue for non invasive monitoring of a variety of physiological and pathological conditions.

Aims: Because albumin is the most abundant protein in the body and is synthesized by the liver, the current study was designed to assess plasma albumin mRNA ( $A L B$ mRNA), as a non invasive diagnostic marker of liver injury in chronic HCV (CHC) and hepatocellular carcinoma (HCC).

Patients and Methods: The study included 65 patients, 31 patients had $\mathrm{CHC}$ and 34 were of $\mathrm{HCC}$ as well as 25 healthy control subjects. Patients were subjected to clinical examination, abdominal ultrasonography, CT for HCC cases and laboratory investigations including liver function tests, AFP and plasma albumin mRNA by Real Time- PCR.

Results: Patients with $\mathrm{CHC}$ and $\mathrm{HCC}$ have a significant increase in their plasma ALB mRNA than controls; the higher level was in HCC cases. At a cut-off >935 copies/ml, plasma ALB mRNA can discriminate liver diseased from healthy subjects, with a sensitivity of $81.5 \%$, and specificity of $96 \%$, while, elevated serum levels of ALT had a sensitivity of $32.3 \%$, and specificity of $92 \%$. However, at a cut off $>20$ $\mathrm{ng} / \mathrm{ml}$ alpha feto protein (AFP) had a sensitivity of $55.9 \%$ and sensitivity of $91.2 \%$.in diagnosis of HCC.

Conclusion: ALB mRNA in plasma is liver specific; it is increased in liver disease suggesting liver pathology and may be more diagnostically sensitive than alpha-fetoprotein and Alanine aminotransaminase (ALT) serum levels. Thus, future studies should assess if the plasma concentration of $A L B$ mRNA may be used as therapy monitoring.
\end{abstract}




\section{Introduction}

The clinical course of untreated hepatitis $\mathrm{C}$ virus $(\mathrm{HCV})$ infection is highly variable with the majority of patients experiencing a slow fluctuating disease that may take 20 years or more for full expression. Approximately half of $\mathrm{HCV}$ patients develop chronic active hepatitis and this may progress to liver cirrhosis and hepatocellular carcinoma (HCC) [1].

Hepatic fibrosis is the accumulation of extracellular matrix, or scar, in response to acute or chronic liver injury. Fibrogenesis represents a wound healing response to injury, and ultimately leads to cirrhosis. Both fibrosis and cirrhosis are the consequences of a sustained wound-healing response to chronic liver injury from a range of causes, including viral, autoimmune, drug induced, cholestatic and metabolic diseases [2,3].

The development of severe fibrosis and necroinflamatory changes in liver leads to cirrhosis and worsens prognosis by enhancing the risk of HCC. Chronic HCV varies greatly in its course and outcome. The presence of HCV RNA indicates that the patient has ongoing viral infection despite normal ALT levels [4]. Serologic assays detect $\mathrm{HCV}$ antibodies that indicate present or previous infection, but they cannot discriminate acute from chronic or resolved infection. Occasionally immunocompromised patients, patients undergoing hemodialysis and patients with mixed cryoglobulinemia have false negative serology results and may require $\mathrm{HCV}$ RNA listing for diagnosis [5]. While needle biopsy is still the mainstay in diagnosing hepatic fibrosis, its days of dominance seem limited as laboratory technology and imaging studies improve.

The existence of extracellular mRNA in the circulation, i.e., plasma and other body fluids has been long known [6]. The extracellular mRNA is thought to be released into the circulation from intact and viable cells as well as necrotic cells [7]. The biological roles of circulating mRNA are still unclear, although its physiological significance has been investigated during the last several years.

The detection of circulating RNA offers certain advantages over the detection of circulating DNA [8]. First, if both plasma RNA and DNA were derived from the same cell population, the released RNA would likely be quantitatively more abundant than DNA. This is because multiple copies of an RNA transcript may be present in each cell, depending on the gene's expression, whereas each cell contains only a single diploid genome equivalent of DNA. Second, some cancer researchers reported that a greater proportion of cancer cases were positive for the investigated plasma RNA markers than DNA markers [9].

The analysis of circulating nucleic acids in plasma offers an avenue for non invasive monitoring of a variety of physiological and pathological conditions [10,11]. The plasma circulating mRNA in cancer patients [12] and pregnant women [13] has been detected and analyzed with respect to sensitivity and specificity. An increasing amount of evidence suggests that liberation of cell-free nucleic acids into plasma from organs or compartments is likely to be due to cell death $[14,15]$.

The detection and monitoring of hepatic injury or dysfunction of patients infected with hepatitis $\mathrm{B}$ and $\mathrm{C}$ are increasingly becoming important. Currently plasma aminotransferases such as ALT and aspartate aminotransferase (AST) are conventionally used to assess hepatic injury, however, it is well known that they lack specificity and sensitivity, and their levels vary in different populations and at different time points in an individual [16]. Reliable and sensitive molecular markers have been awaited.

The analyses of cell free RNA species successfully detected in plasma have potential for use in disease assessment [13]. There is much evidence to suggest that circulating DNA and RNA are released upon cell death [15]. Indeed, reports of previous studies have described the detection of $A L B$ mRNA in peripheral whole blood and the peripheral mononuclear cell fraction 
of humans [17,18]. These studies have had a mixed level of success, however, with detection rates of blood $A L B$ mRNA of $>100 \%$ from patients with HCC [19], cirrhosis, or hepatitis and from healthy controls. The correlation of plasma $A L B$ mRNA concentration with hepatic injury in rats have been reported [20], however, the studies in human is still lacking.

The aim of the current study is to measure the level of circulating plasma mRNA released from damaged hepatocytes by quantitative Real TimePCR, and compare its sensitivity to that of serum ALT and other markers of liver injury in patients with chronic HCV and HCC.

\section{Patient and methods}

\subsection{Patients}

The study included 65 patients (41 males and 24 females, age range 31- 56 years) attending the outpatient and inpatient clinic of the Hepatology Department-National Liver Institute- Menoufiya University and Internal Medicine Department of Al Zahraa University Hospital, Egypt, from May 2009 till September 2010.

Thirty one patients were with chronic HCV (CHC) (21 males and 10 females), were selected according to the following criteria: the presence of anti $\mathrm{HCV}$ antibodies, detection of serum $\mathrm{HCV}$ RNA, negative results for hepatitis B surface antigen and the histopathological features in liver biopsy samples. The remaining 34 patients were of HCC (20 males and 14 females), who were diagnosed according to clinical examination, radiological investigations including abdominal ultrasonography and triphasic CT abdomen. CTP score was also done, and laboratory investigations including AFP. The study was approved by the local ethical committee in university hospitals and informed consent was obtained from the patients.

Exclusion criteria: The patients with known previous history of haematological malignancies or any malignancy, autoimmune diseases or any genetic diseases as well as patients with chronic liver disease not HCV related were excluded.

In addition, 25 healthy subjects (16 males and 9 females, age range 27- 55 years) were used as controls, they had normal values of serum alanine aminotransferase (ALT) and were seronegative for hepatitis B surface markers (HBs $\mathrm{Ag}, \mathrm{HBe} \mathrm{Ag}$ and $\mathrm{HBc}-\mathrm{Ab})$ And HCV.

All patients were subjected to full history taking, thorough clinical examination and the following investigations: abdominal ultrasonogrphy, Laboratory investigations including hepatic transaminases (AST and ALT), albumin, total and direct bilirubin, and alkaline phosphatase.These tests were measured using Integra-400 (Roche-Germany). Prothrombin concentration was done by Fibrintimer (Dade Behring-Germany). Complete blood cell counts were measured by Sysmix K-21 automatic cell counter (Japan). Serum AFP was measured using automated Eleceyes (Roche- Diagnostic, Branchburg, NJ- Germany). HCV and HBV antibodies were assayed by EIA (COBASAmplicore, Germany). HCV-RNA levels were analyzed by reverse transcriptase polymerase chain reaction (RT-PCR) using a commercial kit (Roche Diagnostic, Branchburg, NJ-Germany) according to the manufacturer's instructions.

Ultrasound guided liver biopsy was performed by true-cut needle or liver biopsy gun for all patients and histological grading and staging were performed using a modified Knodell scoring system by a pathologist blinded to the clinical data [21].

\subsection{Sample collection and RNA extraction}

Blood samples were collected into EDTA vacutainer tubes and samples were kept at $4{ }^{\circ} \mathrm{C}$ and processed within $4 \mathrm{~h}$. After gentle mixing of the whole-blood sample, $0.3 \mathrm{~mL}$ was mixed with $0.9 \mathrm{~mL}$ of TRIzol LS reagent (Invitrogen). Buffy coat was isolated after centrifugation at $230 \mathrm{~g}$ for 5 min at $4{ }^{\circ} \mathrm{C}$ to remove any residual plasma and all samples were stored until nucleic acid extraction, as described [22]. Total RNA was isolated from the plasma supernatant using QIAamp MinElute Virus Vacuum kit (Qiagen, Valencia, CA, U.S.A.) and treated with DNase using TURBO-DNA-free kit (Ambion Inc., Austin, TX, U.S.A.) according to manufacturer's instructions. Aliquots of total RNA were reverse transcribed into cDNA with SuperScript IIITM First-Strand Synthesis System (Invitrogen Corp., Carlsbad, CA, U.S.A.). 


\subsection{Quantitative Real Time- PCR albumin mRNA (ALB mRNA)}

PCR TaqMan probes for human albumin (NM_134326) and human beta-actin as internal control (NM_031144) were purchased from Applied Biosystems (Foster City, CA, U.S.A.), and the real-time quantitative RT-PCR was set up with Platinum Quantitative PCR SuperMix-UDG with ROX (Invitrogen Corp.) in a total volume of $20 \mu l$. Calibration curves for absolute $A L B$ mRNA quantification were prepared by amplifying serial dilutions of HPLC-purified synthetic DNA oligonucleotides specific for the targeted $A L B$ amplicon [23] at concentrations of 3 copies to $3 \mathrm{x}$ $10^{6}$ copies per reaction well. The amplification of $A L B$ mRNA was monitored with an ABI Prism 7900 Sequence Detection System (Applied Biosystems) and Sequence Detection Software version 2.2 (Applied Biosystems). Absolute concentrations of $A L B$ mRNA in plasma were expressed as the number of copies / $\mathrm{ml}$ [24].

\subsection{Statistical analysis}

Data are expressed as mean \pm SD. The SPSS computer program version 12.0 was used for statistical analysis. Chi square ( $\mathrm{X}^{2}$ test) was used for qualitative data. Kruskal-Wallis test was done to compare three or more of non normally distributed variables and Tamhane test is a Post Hoc test done to variables of significant difference of more than two groups of not normally distributed data after Kruskal-Wallis test to detect the significant difference between either groups. Correlation coefficients (r) were calculated using the Pearson's correlation analysis. $p$ value was significant at $<0.05$ level. Sensitivity, specificity, positive predictive value (PPV) and negative predictive value (NPV) were determined.

\section{Results}

Results obtained are presented in tables 1-5 and figure (1). The study includes 34 patients had HCC (20 males and 14 females), age range 43- 56 years with mean years of $50.1 \pm 7.2$, and 31 patients had HCV (21 males and 10 females), age

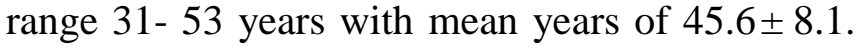
Twenty five healthy subjects (16 males and 9 females), age range 27- 52 years with mean years of $39.8 \pm 6.9$

Table (1) describes patient statistics of demographic data, the male gender, hepatomegaly, splenomegaly, jaundice, hematemesis and melena were not significantly different among both groups ( $>0.05)$. While ascites was significantly increased in HCC cases.

The comparison between liver function tests in the studied groups revealed that a significant increase in ALT, AST, ALP, GGT and total bilirubin in patients with $\mathrm{HCV}$ and $\mathrm{HCC}$ compared controls. While, serum albumin, prothrombin concentration and platelets were significantly decreased (Table 2).

AFP serum levels were significantly increased in chronic $\mathrm{HCV}$ and $\mathrm{HCC}$ cases compared to control group, its levels in HCC patients was significantly higher than in chronic $\mathrm{HCV}$ patients. A significant increase in plasma ALB mRNA was detected in chronic HCV and HCC patients as compared to control subjects $(\mathrm{p}<0.01)$ for each, and its level was significantly higher in HCC cases than in cases of chronic HCV (Table 3).

The data from all groups ( $\mathrm{HCV}$ and $\mathrm{HCC}$ ) showed that plasma $A L B$ mRNA concentration correlated with ALT level $(\mathrm{r}=0.65$; $\mathrm{P}<0.01 \& \mathrm{r}=$ 0.59 ; $\mathrm{P}<0.05)$ for chronic $\mathrm{HCV}$ and $\mathrm{HCC}$ respectively. Also, it was correlated with viral load $(\mathrm{r}=0.52 ; \mathrm{P}<0.05 \& \mathrm{r}=0.48 ; \mathrm{P}<0.05)$ for chronic $\mathrm{HCV}$ and $\mathrm{HCC}$ respectively. While, $A L B$ mRNA was not correlated with alkaline phosphatase $(r=0.133 ; P>0.05)$, total bilirubin $(\mathrm{r}=0.11 ; \mathrm{p}>0.05)$ or AFP serum level $(r=0.19$; $P>0.05)$ (Table 4).

At a cut-off $>935$ copies/ $\mathrm{ml}$ the ALB mRNA can discriminate patients with liver injury (overall 65 liver disease patients) from healthy subjects $(\mathrm{N}=25)$, with a sensitivity of $81.5 \%$, and specificity of $96 \%$. While, the serum levels of ALT was elevated (> $55 \mathrm{U} / \mathrm{L}$ ) in only 21 patients out of 65 patients, with a sensitivity of $(32.3 \%)$, and 3 cases had increased ALT among 25 healthy subjects with specificity of $(92 \%)$ for diagnosing liver disease (Table 5).

However, AFP was $>20 \mathrm{ng} / \mathrm{ml}$ in 19 out of 34 with a sensitivity of $55.9 \%$ in diagnosis of $\mathrm{HCC}$, 
31 of them had increased ALB mRNA with a sensitivity of $91.2 \%$.

\section{Discussion}

There is much excitement about the possibility of developing blood-based tools for disease diagnosis and management through the analysis of circulating nucleic acids [10,25].
Indeed, studies have reported the presence of circulating $A L B$ mRNA, but with varying degrees of success $[17,26]$. The liver being one of the largest organs of the body, suspect that RNA expressed by genes in the liver, such as $A L B$, should be detectable in the peripheral circulation because of cell death associated with typical cell turnover and/or with pathological damage [24].

Table 1. Demographic data of the studied patient groups

\begin{tabular}{lllll}
\hline \multirow{2}{*}{ Variables } & \multicolumn{2}{c}{ Patient Groups } & \multicolumn{2}{c}{ X- } \\
\cline { 2 - 3 } & $\begin{array}{l}\text { CHC (N=31) } \\
\text { No (\%) }\end{array}$ & $\begin{array}{l}\text { HCC }(\mathbf{N}=34) \\
\text { No }(\%)\end{array}$ & Value \\
\hline Gender (male \%) & $21(67.8 \%)$ & $20(58.8 \%)$ & 0.09 & $>0.05$ \\
\hline Hepatomegaly & $23(74.2 \%)$ & $27(79.4 \%)$ & 0.21 & $>0.05$ \\
\hline Splenomegaly & $19(61.3 \%)$ & $23(67.6 \%)$ & 0.19 & $>0.05$ \\
\hline Jaundice & $12(38.7 \%)$ & $19(55.9 \%)$ & 2.27 & $>0.05$ \\
\hline Hematemesis & $7(22.6 \%)$ & $12(35.3 \%)$ & 3.01 & $>0.05$ \\
\hline Melena & $11(35.5 \%)$ & $10(29.4 \%)$ & 1.58 & $>0.05$ \\
\hline Ascites & $5(16.1 \%)$ & $18(52.9 \%)$ & 4.16 & $<0.05$ \\
\hline P<0.05 & & &
\end{tabular}

$\mathrm{P}<0.05$ is statistically significant, $\mathrm{p}>0.05$ is not statistically significant.

Table 2. Comparison of Liver function tests in patient and control groups

\begin{tabular}{|c|c|c|c|c|c|}
\hline $\begin{array}{l}\text { Post Hoc } \\
\text { test } \\
\text { p- value }\end{array}$ & $\begin{array}{c}\text { P- } \\
\text { Value }\end{array}$ & $\begin{array}{c}\text { Controls } \\
(\mathrm{N}=25) \\
\text { Mean } \pm \mathrm{SD}\end{array}$ & $\begin{array}{c}\text { HCC } \\
(\mathrm{N}=34) \\
\text { Mean } \pm \mathrm{SD}\end{array}$ & $\begin{array}{c}\mathrm{CHC} \\
(\mathrm{N}=31) \\
\text { Mean } \pm \mathrm{SD}\end{array}$ & $\overline{\text { Studied variables }}$ \\
\hline $\begin{array}{l}\mathrm{P} 1=<0.01 \\
\mathrm{P} 2=<0.01 \\
\mathrm{P} 3=>0.05\end{array}$ & $<0.01$ & $16.9 \pm 4.2$ & $121.3 \pm 85.2$ & $134.6 \pm 89.1$ & ALT (U/L) \\
\hline $\begin{array}{l}\mathrm{P} 1=<0.01 \\
\mathrm{P} 2=<0.05 \\
\mathrm{P} 3=>0.05\end{array}$ & $<0.01$ & $17.4 \pm 6.5$ & $126.2 \pm 89.8$ & $102.5 \pm 72.8$ & $\operatorname{AST}(\mathrm{U} / \mathrm{L})$ \\
\hline $\begin{array}{l}\mathrm{P} 1=<0.05 \\
\mathrm{P} 2=<0.01 \\
\mathrm{P} 3=<0.05\end{array}$ & $<0.01$ & $29.3 \pm 8.6$ & $132.3 \pm 93.1$ & $56.4 \pm 24.3$ & $\operatorname{ALP}(\mathbf{U} / \mathbf{L})$ \\
\hline $\begin{array}{l}\mathrm{P} 1=<0.05 \\
\mathrm{P} 2=<0.01 \\
\mathrm{P} 3=<0.01\end{array}$ & $<0.01$ & $22.6 \pm 7.4$ & $131.6 \pm 79.4$ & $32.1 \pm 10.2$ & GGT (U/L) \\
\hline $\begin{array}{l}\mathrm{P} 1=<0.01 \\
\mathrm{P} 2=<0.01 \\
\mathrm{P} 3=>0.05\end{array}$ & $<0.01$ & $0.62 \pm 0.17$ & $3.894 \pm 2.16$ & $3.5 \pm 1.96$ & Total Bil (mg/dl) \\
\hline $\begin{array}{l}\mathrm{P} 1=<0.05 \\
\mathrm{P} 2=<0.05 \\
\mathrm{P} 3=>0.05\end{array}$ & $<0.05$ & $4.13 \pm 0.29$ & $2.96 \pm 0.35$ & $3.11 \pm 0.41$ & Serum alb. (gm/dl) \\
\hline
\end{tabular}




\begin{tabular}{|l|l|l|l|l|l|}
\hline $\begin{array}{l}\mathrm{P} 1=<0.01 \\
\mathrm{P} 2=<0.01 \\
\mathrm{P} 3=>0.05\end{array}$ & $<0.01$ & $95.3 \pm 3.59$ & $62.5 \pm 10.8$ & $66.5 \pm 14.3$ & $\begin{array}{l}\text { Proth. Con. } \\
(\%)\end{array}$ \\
\hline $\begin{array}{l}\mathrm{P} 1=<0.01 \\
\mathrm{P} 2=<0.01 \\
\mathrm{P} 3=<0.05\end{array}$ & $<0.01$ & $267.5 \pm 58.3$ & $132.6 \pm 28.7$ & $152.3 \pm 42.6$ & $\begin{array}{l}\text { Platelets } \\
(\mathbf{x 1 0} / \mathbf{u l})\end{array}$ \\
\hline
\end{tabular}

$\mathrm{P} 1=$ between controls and chronic HCV, $\mathrm{P} 2=$ between $\mathrm{HCC}$ and controls, $\mathrm{P} 3=$ between HCV and HCC patients.

Table 3. Comparison of AFP and ALB mRNA in patient and control groups

\begin{tabular}{|c|c|c|c|c|}
\hline $\begin{array}{l}\text { Post Hoc } \\
\text { test } \\
\text { p- value }\end{array}$ & $\begin{array}{l}\text { trols } \\
\qquad(\mathrm{N}=25)\end{array}$ & $\begin{array}{r}\text { HCC Group } \\
\quad(\mathrm{N}=34)\end{array}$ & $\begin{array}{c}\text { CHC Group } \\
(\mathrm{N}=31)\end{array}$ & Studied variables \\
\hline $\begin{array}{l}\mathrm{P} 1=<0.05 \\
\mathrm{P} 2=<0.01 \\
\mathrm{P} 3=<0.01\end{array}$ & $\begin{array}{c}1.8-4.2 \\
2.39 \pm 1.43\end{array}$ & $\begin{array}{c}186-7350 \\
3651 \pm 3456\end{array}$ & $\begin{array}{c}12-85 \\
45.3 \pm 28.4\end{array}$ & $\begin{array}{l}\text { AFP }(\mathbf{n g} / \mathbf{m l}): \\
\text { Range } \\
\text { Mean } \pm \text { SD }\end{array}$ \\
\hline $\begin{array}{l}\mathrm{P} 1=<0.01 \\
\mathrm{P} 2=<0.01 \\
\mathrm{P} 3=<0.01\end{array}$ & $\begin{array}{c}0-2300 \\
250\end{array}$ & $\begin{array}{c}210-49000 \\
4200\end{array}$ & $\begin{array}{c}100-37000 \\
2800\end{array}$ & $\begin{array}{l}\text { ALB mRNA } \\
\text { (copies/ml): } \\
\text { Range } \\
\text { Median }\end{array}$ \\
\hline
\end{tabular}

$\mathrm{P} 1=$ between controls and $\mathrm{CHC}, \mathrm{P} 2=$ between $\mathrm{HCC}$ and controls, $\mathrm{P} 3=$ between $\mathrm{CHC}$ and $\mathrm{HCC}$ patients

Table 4. Correlation between $A L B$ mRNA levels and parameters of liver injury

\begin{tabular}{|c|c|c|c|c|}
\hline \multirow{3}{*}{ Variables } & \multicolumn{4}{|c|}{$A L B$ mRNA levels } \\
\hline & \multicolumn{2}{|c|}{$\begin{array}{c}\text { CHC patients } \\
(\mathrm{N}=31)\end{array}$} & \multicolumn{2}{|c|}{$\begin{array}{c}\text { HCC patients } \\
(\mathrm{N}=34)\end{array}$} \\
\hline & $\mathrm{r}$ & $\mathrm{p}$ & $\mathrm{r}$ & $\mathrm{P}$ \\
\hline ALT & 0.65 & $<0.01$ & 0.59 & $<0.05$ \\
\hline ALP & 0.13 & $>0.05$ & 0.07 & $>0.05$ \\
\hline Total bilirubin & 0.11 & $>0.05$ & 0.16 & $>0.05$ \\
\hline Viral load & 0.52 & $<0.05$ & 0.48 & $<0.05$ \\
\hline AFP & 0.19 & $>0.05$ & 0.26 & $>0.05$ \\
\hline
\end{tabular}

Table 5. The sensitivity and specificity of ALB mRNA and ALT in diagnosis of liver disease (N=65)

\begin{tabular}{|l|c|c|c|}
\hline Studied variables & Cut-off & Sensitivity & Specificity \\
\hline ALB mRNA (copies/ml) & 935 & $81.5 \%$ & $96 \%$ \\
\hline ALT (U/L) & 54 & $32.3 \%$ & $92 \%$ \\
\hline
\end{tabular}




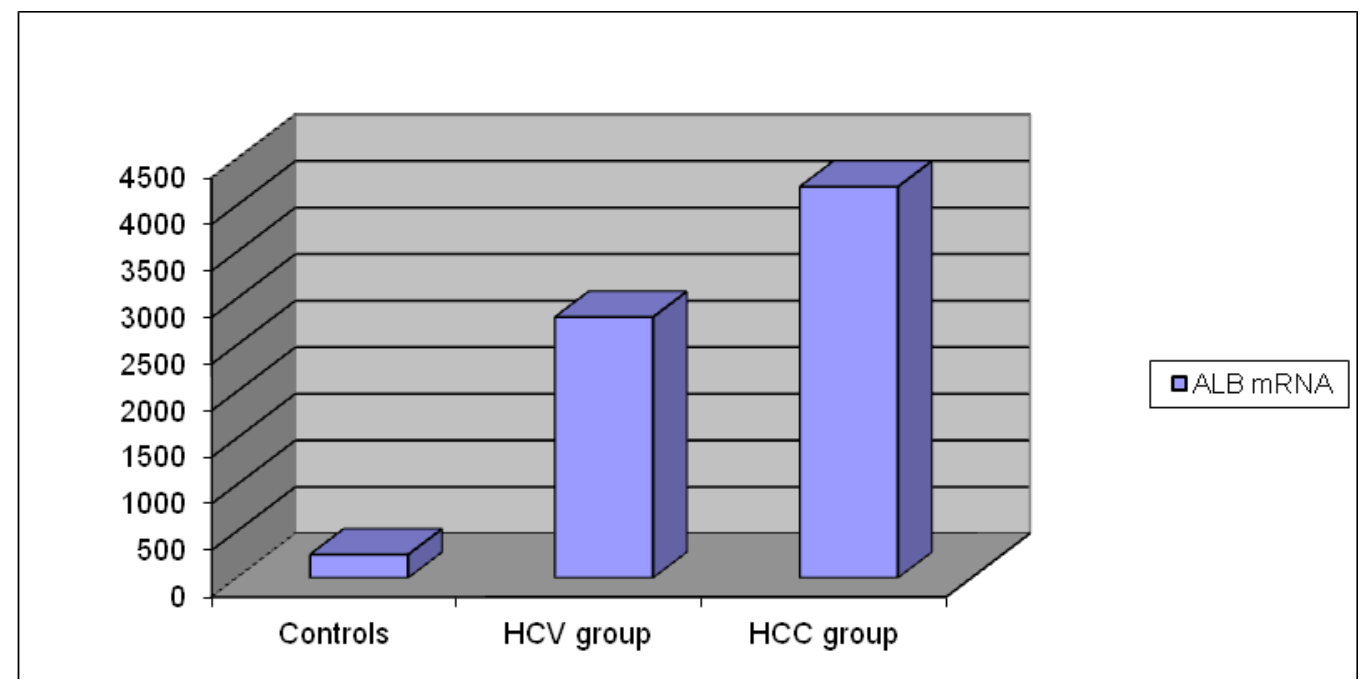

Figure 1. The serum levels of ALB mRNA in controls and patient groups

Some researchers have suggested that ALB mRNA in blood originates from malignant or non malignant hepatocytes that have entered the peripheral circulation $[27,28]$. For that, the present study was designed to evaluate the potential of circulating ALB mRNAs as biomarkers of liver injury in chronic $\mathrm{HCV}$ and $\mathrm{HCC}$ in spite of normal ALT or AFP. The Real Time- PCR was used to quantify ALB mRNA in plasma of chronic $\mathrm{HCV}$ and $\mathrm{HCC}$ patients.

The current study revealed that, A significant increase in ALB mRNA in plasma of chronic $\mathrm{HCV}$ and $\mathrm{HCC}$ patients more than controls, its level was significantly higher in HCC cases than in cases of chronic HCV. Our finding is in agreement of [24] who demonstrated that, patients with HCC, cirrhosis, and active CHB (but not those with inactive hepatitis $B$ carrier) had significantly higher plasma $A L B$ mRNA concentrations than controls, and the $A L B$ mRNA detected in plasma is liver specific. These data suggest that $A L B$ mRNA may be released into the plasma upon cell death, and therefore the concentration may correlate with the degree of cell death.

A recent study used quantitative RT-PCR to investigate the role of plasma $A L B$ mRNA detection for predicting HCC recurrence in liver transplant recipients and reported a detection rate of $82 \%$ [26]. The authors of the report believed that the absence of detectable $A L B$ mRNA in the plasma of the study participants indicated a lack of HCC cells in the circulation.

Plasma albumin mRNA quantification predicts post-transplant $\mathrm{HCC}$ recurrence. It may supplement the current selection criteria of HCC patients for liver transplantation [29].

Serum aminotransferases have been the clinical standard for evaluating liver injury for the past 50-60 years. These tissue enzymes lack specificity, also tracking injury to other tissues. New technologies assessing tissue-specific messenger RNA (mRNA) release into blood should provide greater specificity and permit indirect assessment of gene expression status of injured tissue (30).

At a cut-off $>935$ copies/ml the ALB mRNA can discriminate liver patients from healthy subjects, with a sensitivity of $81.5 \%$, and specificity of $96 \%$. While, the serum levels of ALT was elevated in 21 cases in overall 65 patients, with a sensitivity of $32.3 \%$, and 3 cases had increased ALT among 25 healthy subjects with specificity of $92 \%$ for diagnosing liver disease. However, AFP was $>20 \mathrm{ng} / \mathrm{ml}$ in 19 out of 34 with a sensitivity of $55.9 \%$ in diagnosis of HCC, 31 of them had increased ALB mRNA with a sensitivity of $91.2 \%$.

A recent study by Chan et al. (2009) showed that, ROC curve analysis demonstrated plasma $A L B$ mRNA measurement to be an attractive means for detecting the presence of liver 
pathology (91.9\% of patients). In particular, for the HCC group, AFP was increased in only $48.6 \%$ of the cases, whereas the majority $(91.4 \%)$ of these patients showed increased $A L B$ mRNA concentrations.

The comparative analysis of circulating liver mRNAs with traditional serum transaminases and histopathology indicated that the circulating liver mRNAs were more specific and more sensitive biomarkers of liver injury [30]. In case that any mRNA is detected either earlier or with higher sensitivity than plasma aminotransferases, it may serve as a non-invasive liver fibrosis marker, which will greatly impact on diagnosis and monitoring of liver fibrosis and cirrhosis patients [31].

The plasma circulating albumin mRNA may serve as a molecular marker for hepatic injury using the acute and chronic rat liver fibrosis models [20]. The measurement of plasma circulating albumin mRNA enabled sensitive and early detection of hepatic injury with a large assay window compared with that of plasma ALT activity.

The plasma levels of conventional markers for hepatotoxicity, ALT and AST, can rise as a result of extra hepatic damage, for instance, skeletal muscle damage [32], making the evaluation of ALT and AST changes problematic. On the other hand, in experimental study, it was confirmed that albumin mRNA was not detectable in peripheral blood from rats with skeletal muscle damage [33].. However, if liverspecific mRNAs in peripheral blood were evaluated concurrently, it would be possible to exclude liver damage.

The circulating cell-free mRNA can be protected from degradation by being contained in particles such as apoptotic bodies [34] . Additionally, several findings have indicated that extracellular RNA might be protected from serum RNases by proteins or proteolipid complexes $[35,36]$.

The cell-free organ/tissue-specific mRNAs in the peripheral blood have several characteristics that satisfy the requirements for good biomarkers. First, mRNAs are accessible and non invasive because they can be easily obtained from peripheral blood. Second, the assay methods theoretically can be established with ease and in a short time if the nucleotide sequence of the target mRNA is already known. Third, if the mRNA is expressed similarly between rodent and human and if it shows similar organ/tissue specificity, the assay methods could be readily applied to both species. These characteristics are beneficial in transferring the technology from non clinical studies to clinical trials [33].

Considering the data from all of the study patient groups (CHC and HCC) showed that plasma $A L B$ mRNA concentration correlated with ALT level and viral load, but it was not correlated with AFP serum level, suggesting its elevation accompanied HCC cases in spite of normal AFP levels. These findings are in accordance with Chan et al. (2009) [24], who reported that plasma $A L B$ mRNA concentration showed some correlation with serum ALT activity. Plasma $A L B$ mRNA was also increased in patients who had liver disease but non pathologic ALT values. These observations suggest that plasma $A L B$ mRNA may be a diagnostically sensitive marker for detecting early stage chronic liver disease, when the ALT activity or concentration is often within the reference interval.

\section{Conclusion}

In summary, we conclude that, the measurement of plasma circulating albumin mRNA enabled sensitive and early detection of non-invasive diagnostic marker for hepatic injury in liver fibrosis and HCC compared with that of plasma ALT activity and serum AFP levels. Further studies are required, however, to investigate the clinical utility of this marker for assessing or managing such diseases. However, larger sample sets including long-term clinical data are urgently required for future studies.

\section{References}

1. Banker, P.D. Viral hepatitis, Ind. J. Med. Sci., 2003, 57, 461-468.

2. Fattovich, G.; Giustina, G.; Degos, F.; et al. Morbidity and mortality in compensated cirrhosis type $\mathrm{C}$ : a retrospective follow-up 
study of 384 patients, Gastroenterology, 1997, 112, 463-472. doi:10.1053/gast.1997.v112.pm9024300

3. Rockey, D.C.; Friedman, S.L. Hepatic fibrosis and cirrhosis; New York, 2007; pp 87-109.

4. Berry, V.; Arora, R.R.; Paul, P. Hepatitis CClinical Outcome and Diagnosis. JK Science, 2005, 7 (3), 129-132. PMid: 9567513

5. Thio, C.L.; Nolt, K.R.; Astemborski, J.; et al. Screening for hepatitis $\mathrm{C}$ virus in human immunodeficiency virus infected individuals, J. Clin. Mircobiol., 2000, 38, 575-577.

6. Swaminathan, R.; Butt, A.N. Circulating nucleic acids in plasma and serum: Recent development, Ann. N.Y. Acad. Sci., 2006, 1075, 1-9. doi:10.1196/annals.1368.001

7. Fleischacker, M. Biology of circulating mRNA: Still questions than answers?. Ann. N.Y. Acad. Sci., 2006, 1075, 40-49. doi:10.1196/annals.1368.005

8. Lambrechts, A.C.; van't Veer L.J.; Rodenhuis, S. The detection of minimal numbers of contaminating epithelial tumour cells in blood or bone marrow: use limitations and future of RNA-based methods. Ann. Oncol. $\quad 1998, \quad 9, \quad 1269 \quad-1276$. doi:10.1023/A:1008445604263

9. Anker, P.; Mulcahy, H.; Stroun, M. Circulating nucleic acids in plasma and serum as a non-invasive investigation for cancer: time for large-scale clinical studies? Int $\mathrm{J}$ Cancer, 2003, 103, 149-152. doi:10.1002/ijc.10791

10. Chan, A.K.C.; Chiu, R.W.K.; Lo, Y.M.D. Cell-free nucleic acids in plasma, serum and urine: a new tool in molecular diagnosis, Ann. Clin. Biochem., 2003, 40, 122-130. doi: $10.1258 / 000456303763046030$

11. Lo, Y.M.D.; Chiu, R.W.K. The biology and diagnostic applications of plasma RNA, Ann. N.Y. Acad. Sci., 2004, 1022, 135-139. doi:10.1196/annals.1318.022

12. Miura, N.; Maeda, Y.; Kanbe, T.; et al. Serum human telomerase reverse transcriptase messenger RNA as a novel tumor marker for hepatocellular carcinoma, Clin. Cancer. Res., 2005, 11, 3205-3209. doi:10.1158/1078-0432.CCR-04-1487
13. Ng, E.K.O.; Tsui, N.B.Y.; Lau, T.K.; et al. mRNA of placental origin is readily detectable in maternal plasma. Proc. Natl. Acad. Sci. U.S.A., 2003, 100, 4748-4753. doi:10.1073/pnas.0637450100

14. Fournie, G.J.; Courtin, J.P.; Laval, F.; et al. Plasma DNA as a marker of cancerous cell death. Investigations in patients suffering from lung cancer and in nude mice bearing human tumours. Cancer Lett. 1995, 91, 221227. doi:10.1016/0304-3835(95)03742-F

15. Jahr, S.; Hentze, H.; Englisch, S.; et al. DNA fragments in the blood plasma of cancer patients: quantitation and evidence for their origin from apoptotic and necrotic cells, Cancer Res., 2001, 61, 1659-1665. PMid: 11245480

16. Janssen, G.M.E.; Kupipers, H.; Geurten, P.; et al. Quantification of skeletal muscle damage and relationship with metabolic variables. J. Int. Sports. Med, 1989, 10, S123-S128. PMid: 2599735

17. Wong, I.H.; Lau, W.Y.; Leung, T.; Johnson, P.J. Quantitative comparison of alphafetoprotein and albumin mRNA levels in hepatocellular carcinoma/adenoma, nontumour liver and blood: implications in cancer detection and monitoring. Cancer Lett., 2000, 156, 141-149. doi:10.1016/S0304-3835(00)00473-0

18. Bastidas-Ramirez, B.E.; Panduro, A.; et al. Albumin mRNA in peripheral white blood cells of cirrhotic patients with a superimposed alcoholic hepatitis is associated to fatal outcome, Hepatol. Res., 2002, 24, 265. doi:10.1016/S1386-6346(02)00109-2

19. Anker, P.; Stroun, M. Progress in the knowledge of circulating nucleic acids: plasma RNA is particle associated. Can it become a general detection marker for a cancer blood test? Clin. Chem. 2002, 48, 1210 -1211. PMid:12142375

20. Kudo, Y.; Ochii, T.; Shimada, H.; et al. Utility of Plasma Circulating mRNA as a Marker to Detect Hepatic Injury. J. Vet. Med. $\begin{array}{llll}\text { Sci., } & 2008, \quad 70 & \text { (9), } & 993-995 .\end{array}$ doi:10.1292/jvms.70.993

21. Ishak, K.; Baptista, A.; Bianchi, L.; et al. Histological grading and staging of chronic 
hepatitis. J. Hepatol., 1995, 22, 696-699. doi:10.1016/0168-8278(95)80226-6

22. Chiu, R.W.K.; Poon, L.L.M.; Lau, T.K.; et al. Effects of blood-processing protocols on fetal and total DNA quantification in maternal plasma. Clin. Chem., 2001, 47, 1607-1613. PMid:11514393

23. Wong, B.C.K.; Chiu, R.W.K.; Tsui, N.B.Y.; et al. Circulating placental RNA in maternal plasma is associated with a preponderance of 5 mRNA fragments: implications for non invasive prenatal diagnosis and monitoring. Clin. Chem., 2005, 51, 1786-1795. doi:10.1373/clinchem.2005.052340

24. Chan, R.W.Y..; Wong, J.; Chan, H.L.Y.; et al. Aberrant Concentrations of Liver-Derived Plasma Albumin mRNA in Liver Pathologies, Clin. Chem., 2009, 10 (15), 55, 12-20.

25. Lo, Y.M.D.; Chiu, R.W.K. Prenatal diagnosis: progress through plasma nucleic acids. Nat. Rev. Genet., 2007, 8, 71-77. doi:10.1038/nrg1982

26. Cheung, S.T.; Fan, S.T.; Lee, Y.T.; et al. Albumin mRNA in plasma predicts posttransplant recurrence of hepatocellular carcinoma. Transplantation, 2008, 85, 81-87. doi:10.1097/01.tp.0000298003.88530.11

27. Wong, I.H.; Leung. T.; Ho, S.; et al. Semiquantification of circulating hepatocellular carcinoma cells by reverse transcriptase polymerase chain reaction. Br. J. Cancer. 1997, 76, 628-633. doi:10.1038/bjc.1997.436

28. Gion, T.; Taketomi, A.; Shimada, M.; et al. Perioperative change in albumin mRNA levels in patients with hepatocellular carcinoma, Hepatology, 1998, 28, 16631668. doi:10.1002/hep.510280628

29. Tim, C.S.; Tat, F.S.; Ting, L.Y.; et al. Albumin mRNA in Plasma Predicts PostTransplant Recurrence of Patients With Hepatocellular Carcinoma. Transplantation,
2008,

85 ,

81-87.

doi:10.1097/01.tp.0000298003.88530.11

30. Wetmore, B.A.; Brees, D.; Singh, R.; et al. Quantitative analyses and transcriptomic profiling of circulating messenger RNAs as biomarkers of rat liver injury, Hepatology, 2010, $51 \quad$ (6), 2127-2139. doi:10.1002/hep.23574

31. Rockey, D.C.; Bissell, D.M. Non-invasive measures of liver fibrosis. Hepatology, 2006, 43, S113-S120. doi:10.1002/hep.21046

32. Nathwani, R.A.; Pais, S.; Reynolds, T.B.; Kaplowitz, N. Serum alanine aminotransferase in skeletal muscle diseases. Hepatology, 2005, 41, 380-382. doi:10.1002/hep.20548

33. Miyamoto, M.; Yanai, M.; Ookubo, S.; et al. Detection of cell-free, liver-Specific mRNAs in peripheral blood from rats with hepatotoxicity: A Potential Toxicological Biomarker for Safety Evaluation. Toxicological Science, 2009, 106 (2), 538545. doi:10.1093/toxsci/kfn188

34. Hasselmann, D.O.; Rappl, G.; Tilgen, W.; Reinhold, U. Extracellular tyrosinase mRNA within apoptotic bodies is protected from degradation in human serum. Clin. Chem., 2001, 47, 1488-1489. PMid:11468248

35. Rosi, A.; Guidoni, L.; Luciani, A.M.; et al. RNA-lipid complexes released from the plasma membrane of human colon carcinoma cells, Cancer Lett. 1988, 39, 153-160. doi:10.1016/0304-3835(88)90100-0

36. Wieczorek, A.J.; Sitaramam, V.; Machleidt, W.; et al. Diagnostic and prognostic value of RNA-proteolipid in sera of patients with malignant disorders following therapy: First clinical evaluation of a novel tumour marker. Cancer Res., 1987, 47, 6407-6412. PMid:2445471 